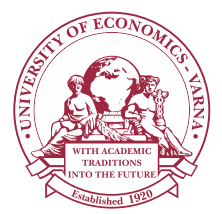

Izvestiya Journal of Varna University of Economics 3 (2021)

IZVEST IYA

Journal of Varna University of Economics

http://journal.ue-varna.bg

\title{
INDUSTRIAL ACTORS' PERCEPTIONS OF INDUSTRIAL DISPUTES IN PUBLIC UNIVERSITIES
}

\section{Johnson FEJOH ${ }^{1}$, Michael Ayodeji BOYEDE ${ }^{2}$, Abiola Olawale SANUSI ${ }^{3}$}

\author{
${ }^{1}$ Institute of Education, Faculty of Education, Olabisi Onabanjo, University, Ago-Iwoye, Ogun \\ State, Nigeria, E-mail: fejoh.johnson@oouagoiwoye.edu.ng \\ ${ }^{2}$ Department of Human Resource Development, Osun State University, Okuku Campus, Osun \\ State, Nigeria, E-mail: michael.boyede@uniosun.edu.ng \\ 3 Centre for Continuing Education, Olabisi Onabanjo University, Ago-Iwoye, Ogun State, Nigeria, \\ E-mail: sanusiabiola01@gmail.com
}

JEL: J52, J53

\section{Key words:}

Industrial actors, university management, academic staff and non-teaching staff, industrial disputes, public universities

\begin{abstract}
There has always been serious concern about how industrial actors in public universities in Nigeria perceive industrial disputes as a means of enforcing collective agreements jointly reached and signed. A group may likely see industrial disputes as unnecessary and destructive while others may see it as a veritable tool for enforcing their labour rights. This study therefore examined the industrial actors' (university management, academic staff and non-teaching staff) perception of industrial disputes in public universities in Southwest, Nigeria. Descriptive research survey design was adopted for the study. The population consisted of the management staff and all the staff of public universities in Southwest, Nigeria. The sample size of the study was 280 respondents (80 management staff, 100 academic staff and 100 non-teaching staff) randomly selected from four public universities across Southwest geo-political zone. Data was collected through a selfdesigned questionnaire. T-test analysis was used to analyze the three hypotheses raised at 0.05 level of significance. Findings revealed that there was significant difference in the way university management, academic and non-teaching staff perceive industrial dispute while there is no significant difference in the way academic and non-teaching staff perceive industrial disputes. It is therefore recommended that all the industrial actors in public universities in Southwest, Nigeria should not see industrial disputes as destructive engagement since disputes are naturally part of organizational existence. Effective management of industrial disputes through sincerity of purpose should be adopted by the industrial actors.
\end{abstract}

(C) 2021 University of Economics - Varna 
Johnson Fejoh, Michael Ayodeji Boyede, Abiola Olawale Sanusi.

Industrial Actors` Perceptions of Industrial Disputes in Public Universities

Citation: FEJOH, Johnson, BOYEDE, Michael A., SANUSI, Abiola, O. (2021) Industrial Actors` Perceptions of Industrial Disputes in Public Universities. Izvestiya Journal of Varna University of Economics, 65 (3), pp. $344-359$.

DOI: 10.36997/IJUEV2021.65.3.344

\section{Introduction}

Industrial actors refer to different groups of people involved in the production process in the workplace. In some climes, they are limited to workers (represented by their unions) and employers (represented by the management). However, in Nigeria it is generally accepted that the government (who plays dual roles as employer of labour and industrial regulatory body) is also an actor in the industrial relations system. The dual roles of government have been a major source of concern to other actors and industrial relations experts. A situation where the regulator is also an actor may be counterproductive during the process of resolving industrial disputes as government will be coming to the negotiation table as a higher, unequal partner in the negotiation and collective bargaining process.

Industrial disputes have been a major source of concern in public universities in Nigeria. These public institutions have been plagued with incessant industrial disputes resulting into prolonged strike actions which have also led to closure and halting of academic activities in these institutions. Wahab (2018) asserts that Academic Staff Union of Universities (ASUU), a major industrial actor in public universities in Nigeria has been on major strike actions fourteen times from 1999 to 2018. This situation clearly underscores the fact that these institutions have not been at peace industrially for most of these periods (Fejoh and Adesanwo, 2021).

Researchers have extensively dealt with causes and effects of industrial disputes on the effective management of public universities and other organizations in Nigeria (Offen, Anashie and Aniah, 2018; Ezeagba, 2014; Omotere, 2014; Ohiwerei and OmoOjugo, 2008). There seems to be a dearth of research on how industrial actors in public universities in Nigeria perceive industrial disputes. This study therefore attempted to examine this important aspect of industrial disputes in public universities in Southwest, Nigeria.

Perceptions of these industrial actors in public universities in Nigeria with regard to industrial disputes are likely to vary. Some groups may see industrial disputes as unnecessary and a waste of precious time during the production process while some other actors may see it as the only way to enforce their labour rights. This paper examined the perceptions of university management, academic staff and non-teaching staff as major industrial actors in public universities in Southwest, Nigeria. Government, as an 
industrial actor does not directly engage in most of industrial disputes in these public institutions. They hide under the fact that the governing councils of various public universities are the employers of labour and these councils are deemed to have autonomy in dealing with all issues relating to industrial relations in these public institutions. It is also noteworthy to state that these governing councils are represented by various university managements. Hence, the decision of the researchers to limit the industrial actors in public universities to university management and workers (academic staff and non-teaching staff).

Conflict, by nature is unavoidable and inevitable in the world of work as long as there is interaction among workers. Industrial disputes appear to be multi-dimensional in characteristics and it seems very frequent within the Nigerian society (Kan and Manfred, 2017). Conflicts among employees and or between employees and employers have over times affected the perception of both university management and workers making them either uncompromising or ambitious in terms of their demands and aspirations especially in the Nigerian ivory-towers.

Industrial disputes have emerged as an important concept in industrial relation system as it has drawn the attention of management scientist and organizational sociologists, and it has been studied with different perspectives and prospects in the organization (Lipskey, Ronald and Ariel, 2015, Igbaji (2009). Adomi and Anie (2005) maintained that the incidence of strike cannot be totally prevented, but conflict that often results from it can be ignored, suppressed or resolved.

Kersley, Alpin, Bryson, Bewley, Dix and Oxenbridge (2006) in a study holds that the outcome of most empirical studies on industrial disputes suggest a kind of variation in terms of causes, factors and nature of conflicts across organizations, adding that industries with higher levels of industrial action at large will experience an increased form of grievance.

Researches across cultures and time have revealed that employees in the world of work especially in the university system are surrounded with diverse concerns and issues among which are issues of low pay, inadequate teaching facilities, refusal or outright inability of government to pay emolument and sundry allowances which goes a long way to create a lacuna in the employee-employer relationship (Agba, Ushie and Agba, 2009). Literature exposed that university workers and their union leaders had suffered several difficulties due to the aftermath of industrial disputes and which to a great length affected their perception toward any conflicts. Despite the availability of both national and international measures to ameliorate the incidence of industrial disputes in the world of work, these efforts remain inadequate in the process of achieving sustainable societal developments (Kolawole, 2019).

In spite of the numerous gains derived from the university based education in 
Johnson Fejoh, Michael Ayodeji Boyede, Abiola Olawale Sanusi.

Industrial Actors` Perceptions of Industrial Disputes in Public Universities

nation development, the Nigerian university system had over the years witnessed series of industrial disputes which have affected its primary goals and objectives.

Contrary to the high expectations of the workers from their employers, the incidence of employees-employers conflicts frequently pave way for stress, frustration, low morale, reduced collaboration, dissatisfaction, high turnover, suicide, absenteeism and poor performance on the job, basically because of what is perceived by lecturers, unions and by different workers unions and their leaders in the system as negligence, non-challant attitude and irresponsibility of the government in meeting promised demands. Perceptions of these industrial actors in public universities in Nigeria with regard to industrial disputes are likely to vary. Some groups may see industrial disputes as unnecessary and a waste of precious time during the production process while some other actors may see it as the only way to enforce their labour rights. The relevance and importance of this research lie in the fact that proper understanding of the industrial actors' perceptions of industrial disputes will assist all the actors whenever they are engaged in collective bargaining process. This understanding will in turn prepare all the actors to approach the resolution of industrial disputes with enough knowledge of the attitudes and perceptions of the parties involved. This paper examined the perceptions of university management, academic staff and non-teaching staff as major industrial actors in public universities in Southwest, Nigeria. Specifically, the study sought to achieve the following objectives:

1. To determine how the university management perceive industrial disputes.

2. To determine how academic staff and non-teaching staff of universities perceive industrial disputes.

\subsection{Research Hypotheses}

The following hypotheses were raised to guide the study:

Ho 1: There is no significant difference in the way university management and academic staff perceives industrial disputes.

Ho 2: There is no significant difference in the way university management and non-teaching staff of universities perceive industrial disputes.

Ho 3: There is no significant difference in the way academic staff and non-teaching staff of universities perceive industrial disputes.

\section{Review of Literature}

\subsection{Theoretical Framework}

Industrial disputes have become an essential part of the industrial relations system in Nigeria due to incessant industrial disputes across most public organizations in 
the country. This study is based on Marxist theory and pluralist theory of industrial relations.

\subsubsection{Marxist Theory}

According to Abu (2007), Marxist theory regards trade unions as sources and medium of power for employees for the purpose of power balancing in work organizations. This position is anchored on the premise that most organizations exist to operate in the interest of the economically dominant class and this presupposes that there exist more considerable conflict between the owners of labour and owners of capital. The only way to resolve conflicts in such situations is through the acquisition of more power at organizational level so that the dominant force will ensure industrial harmony. For the Marxist, the only way that workers can acquire enough power is through the roles of trade unions where they are expected to use their numerical strength to improve the welfare and conditions of service of their members.

\subsubsection{Pluralist Theory}

The Pluralists see the approach as an analogy of the pluralism in the larger society where there exist variety of groups with diverse beliefs and interests. Each group is constrained to protect their beliefs and interests and this lead to disputes. In work organizations, the beliefs and interests of workers and employers differ and this will lead to conflict. It is therefore reasonable to understand that compromise must be reached to accommodate these varying interests and beliefs through negotiation and concession.

\subsection{Conceptual Clarifications}

\subsubsection{Concept of Industrial Dispute}

The term conflict or dispute denotes a struggle between people with opposing needs, ideas, benefits, values or goals. The notion industrial dispute has been seen to be varied in its conceptualization. Kolawole (2019) sees industrial disputes as a disorder or an unrest arising among the workers, management and federal government on any ground. That is, disputes occur among a given set of industrial actors and the outcome of any industrial disputes is always manifested in strikes, lock-out and mass refusal of the workers to perform their duties until the dispute is resolved. Similarity, the Industrial Dispute Act of 1947 identified industrial dispute as differences or disagreement that majorly happened between the employer and the employees, or between the employer and the workmen, or between workmen and workmen. The Act noted that the bane of the disagreement is majorly on the terms of employment, or the conditions of labour of any person. The personality involved in any conflictive display is manifested in terms of:

- Employer and the employees 
Johnson Fejoh, Michael Ayodeji Boyede, Abiola Olawale Sanusi.

Industrial Actors` Perceptions of Industrial Disputes in Public Universities

- Employer and the workmen

- Workmen and workmen

Basically, several schools of thought varied in their views as to the term - industrial disputes. To the traditionalists, conflict is harmful and so, it must be totally avoided in the world of work. Also, the human behaviorists affirmed that conflict is natural in the work system and that it is evitable in any group or, parties or organization, but the interactionists maintained that conflict is not only a positive force but it is also an absolute necessity on the ground that a cordial relationship, peaceful and cooperating attitude can be exchanged for aggression, frustration when the demands are not met (De Dreu, Harinck and Van Vianem, 1999). These views, illustrate that conflict in the world of work can either be dysfunctional or functional depending on how it is embraced (Anku-Tsede and Adjadogo, 2016). Akinbode and Ebeloku (2017) revealed in a study that workplace conflict arises in case of disagreement over workloads problem in communication, individual differences in terms of need, wants, goals, values, opinions or behavior. Holding that conflict can manifest both as intense and unpleasant and that the issues that foster conflict can be cultural, social, political or economic and can emerge at different levels be it individual, community, national or international depending on the terrain at which it operates. In conclusion, Aminu and Marfo (2010) and Rahim (2010) were of the view that conflict in the work place does not submit itself to a single and widely accepted pattern. That is, it can occur within an organization (intra-organization) and between two or more organizations (inter-organization).

\subsubsection{Concept of Perception}

Langton and Robbins (2006) revealed that the term perception denotes the process by which employee and their union leaders organize and interpret their views or impressions in order to give meaning to their environment and to a great length affect their work behaviour. Galpin (1996), Badekale, Ngige and Hamma (2016) adduced that the content of individual employees or labour leaders perception about their work circumstances, terms of employment influence their attitudes, culture and behaviour affect their perceptions towards organizational productivity. The perception of both parties also was that, they will be attentive to important things, ginger interest towards work, maintain satisfaction at work, eliminate work stress, boredom and anxiety, embrace sound communication, and ignore any form of hypertension, coronary problems, peptic ulcers etc. (Omisore and Abiodun, 2014).

Studies affirm that different causes and factors generating conflicts suggested by scholars are more of substantive in their peculiarities. (Van-Tonder and Roodt, 2008). Scholars such as Dahrendorf(1976), Stroh (2002), Robbins, Odendaal and Roodt (2003) see the causes of conflict more at the organizational level. Buttressing that causes of conflict at the organizational level perceived conflict as having a multitude of potential 
sources in terms of causes such as; differences in knowledge, beliefs, values, goals, competition for power, position and recognition, autonomy, differing role structure, heterogeneity of the workplace etc.

Weider-Hatfield and Hatfield (1995), Rahim (2010), Nelson and Quick (2001) in their different studies highlighted structural factors, which are the causes of conflict which developed from within the organization and those causes that originated from individual personal factors or differences. Ajewole (2014) identified that in the Nigerian spectrum, the major causes of industrial dispute manifests in terms of perceived low income, lack of conducive working conditions, National minimum wage by the Federal Government, industrial and economic policies, Federal Government/ Academic Staff Union of Universities (ASUU) 1999 signed agreement, payment of entitlements.

Similarly, Otobo (2005) posits two main sources or causes of industrial disputes; internal and external sources. He asserted that the style of management, nature of physical environment of work place, social consciousness of workers, conditions of service are some of the noted internal sources of organizational conflict and that the external causes of conflict appears as government and industrial policies, nature of labour legislation, national economic mismanagement and general distribution of wealth and power in the societal sphere. In sum, the differences in causes of conflicts as suggested in Otobo (2005), depicts a multi- dimensional approach in its resolution.

The instance of conflict wherever it takes places automatically, do have either a psychological or emotional impacts on the employees (Akinbode, 2019). The perception or morale of employee have greatly been affected and thereby leading to negative form of change on the employees' perception at work, in terms of absenteeism, misconduct, tiredness etc.). In the employee perception of feeling, studies disclosed that disputes have the tendency to create worrisome feeling, resentment, hostility, low productivity, high rate of labour turnover etc., (Tjosvold, 2008).

\subsection{Empirical Review}

Chen, Chen and Chen (2018) in a study on the influence of industrial relations on the management of industrial dispute. It was discovered that there is a significant relationship between dispute management style and industrial dispute resolution. Also, a distinct correlation cannot but exist between employee - employer relations and the ameliorating of industrial conflict. Equally, Longe (2013) revealed in a study that the causal factors of conflict in the world of work are multi- dimensional and they are based on economic and incompatibility of goals in the workplace. Several empirical insights have been identified on the causative factors of industrial disputes. For instance, Hotepo, Asokere, Abdul-Azeez, and Ajemuigbolohun (2010), identified that in a study, the following factors have been the root cause of major industrial disputes such as 
Johnson Fejoh, Michael Ayodeji Boyede, Abiola Olawale Sanusi.

Industrial Actors` Perceptions of Industrial Disputes in Public Universities

lack of resources, divergent expectation, work place competition, lack of cooperative communication breakdown. In addition, Obasan (2011) holds that in the banking sector the causative factors of disputes are: disapproving term of employment, poor human relations between labour and management, non- consultation with labour in making essential decisions, the anti-union posture of management etc. Studies acknowledged the fact that disputes in any organization continue to attract mush controversy, depending on some certain projective instrument. It maintained that amidst the factors that can enhance the progression of any disputes are; actions of the employers and employees, the current relationships with others involved in the conflict, the extent to which they seek towards maintaining relationships into the future, both parties competency in conflict handing (Anku-Tsede and Adjadogo, 2016). They unanimously agreed that these attributes are more related to individuals rather than roles and that labour union possesses unique potential for operating as both relationship managers and preserver of employment relationships. Daria and Bahaudin (2015) confirmed in a study that several conflict structures, types and challenges are likely to occur in diverse workplace in the process of managing conflicts. Likewise, Abdul and Sehar (2015) in their study on conflict management and organizational performance confirmed that education as an instrument does not have any effect on the opinion of respondents on conflict management strategies and that no significant difference exists between the opinion of male and female respondents as regard causes of conflict, but a significant effect of conflict on organizational performance is so glaring; adding that management and government bodies must adopt strategies that will enhance performance, free flow of communication between management and employee and promotion of interpersonal relationships among same workers toward building their morale and organizational perception (Tjosvold, 2008).

Ayoko, Ashkanasy and Jehn (2014) in a study observed that the pattern of industrial conflicts are keen to tasks and relationship and that conflict in the workplace is accompanied by different factors such as emotions of frustration, anger, behavior of yelling, alienation and decline in cooperation among others. Also, in an empirical study on industrial conflict and management, the study revealed that the organizational framework for management of conflict and grievances is poor and that leadership ineffectiveness has been the cause of conflict in the organizations holding that management does not explain its reasons for taking a particular decision in conflict management (Nelson and Quick, 2001). Agba and Ushie (2013) in a study on medical and para-medical staff perception of the impact of wage differential on industrial disputes within the Nigerian hospitals It was revealed that wage differentials of basic salary, hazard and fringe benefit allowance has a significant correlation with industrial disputes in Nigerian hospitals. Also, they maintained that socio-demographic factors 
like sex, age, rank of staff, educational qualification as a propensity to influence the level of industrial conflict in Nigerian hospitals.

\section{Methodology}

The descriptive research survey design was adopted for this study. This research design was aimed at ascertaining detailed information on university management and university workers' perception of industrial disputes in public universities in Southwest, Nigeria. The population for this study was made up of the managements and all the workers of public universities in Southwest, Nigeria. This study was based on the sample size of two hundred and eighty (280) respondents randomly selected from four universities in Southwest, Nigeria (University of Ibadan, Ibadan; Osun State University, Osogbo; Tai-Solarin University of Education, Ijagun, Ijebu-Ode and Federal University of Agriculture, Abeokuta). From this number, each university was represented by twenty (20) management staff made up of six (6) principal officers and fourteen other high ranking management staff of these universities while 50 workers representing 25 academic staff and 25 non-teaching staff from each of the university. The researcher adopted a random sampling technique so as to give the respondents the same chance of being taken.

Primary data was used as a means for data collection and this was achieved by the adoption of a self-structured validated scale comprising of 15 items which were designed to elicit information on the perceptions of university management and workers' perception of industrial disputes in public universities in Southwest, Nigeria. Section (A) of the questionnaire was used to collect data relating to the demographic characteristics of the respondents, which includes the gender, age bracket, marital status, educational question, rank, present designation in the university while section (B) of the questionnaire centers on information on the respondents perception of industrial disputes. The questionnaire was analyzed through the use of statistical packages for social science (SPSS). T-test analysis was used to analyze the data obtained at 0.05 level of significance.

\section{Results and Findings}

Hypothesis One: There is no significant difference in the way university management and academic staff perceive industrial disputes. 
Johnson Fejoh, Michael Ayodeji Boyede, Abiola Olawale Sanusi.

Industrial Actors` Perceptions of Industrial Disputes in Public Universities

Table 1

T-test analysis of difference in the perception

of university management and academic staff

\begin{tabular}{lccccccc}
\hline \multicolumn{1}{c}{ Variables } & N & Mean & SD & t-cal & t-tab & df & P \\
\hline University Management & 80 & 16.435 & 7.827 & 14.49 & 1.96 & 178 & 0.05 \\
Academic Staff & 100 & 15.267 & 3.004 & & & & \\
\hline
\end{tabular}

Table 1 showed a significant difference between university management $(\mathrm{N}=$ $80, \mathrm{X}=16.435, \mathrm{SD}=7.827)$ and academic staff $(\mathrm{N}=100, \mathrm{X}=15.267, \mathrm{SD}=3.004)$ perception of industrial disputes in public university in Southwest, Nigeria. The T-test analysis also revealed that the $t$-cal value 14.9 is greater than the t.tab value of 1.96 at 00.5 level of significance.

Since the calculated value (14.49) is greater than the table value (1.96), the null hypothesis which states that there is no significant difference in the way university management and academic staff perceives industrial disputes is hereby rejected. This signifies that there is significant difference in the way university management and academic staff perceives industrial disputes.

Hypothesis Two: There is no significant difference in the way university management and non-teaching staff of universities perceive industrial disputes.

Table 2

T-test analysis of difference in the perception of university management and non-teaching staff

\begin{tabular}{cccccccc}
\hline Variables & N & Mean & SD & t-cal & t-tab & df & P \\
\hline University Management & 80 & 39.63 & 11.58 & 12.37 & 1.96 & 178 & 0.05 \\
Non-Teaching Staff & 100 & 39.56 & 5.79 & & & & \\
\hline
\end{tabular}

Table 2 showed a significant difference between university management $(\mathrm{N}=$ $80, \mathrm{X}=39.63, \mathrm{SD}=11.58)$ and non-teaching staff $(\mathrm{N}=100, \mathrm{X}=39.63, \mathrm{SD}=5.75)$ perception of industrial disputes in public university in Southwest, Nigeria. The T-test analysis also revealed that the $t$-cal value 12.37 is greater than the t.tab value of 1.96 at 00.5 level of significance.

Since the calculated value (12.37) is greater than the table value (1.96), the null hypothesis which states that there is no significant difference in the way university management and non-teaching staff perceive industrial disputes is hereby rejected. This 
signifies that there is significant difference in the way university management and nonteaching staff perceive industrial disputes.

Hypothesis Three: There is no significant difference in the way academic staff and non-teaching staff of public universities perceive industrial disputes.

Table 3

T-test analysis of difference in the perception of industrial dispute by academic staff and non-teaching staff

\begin{tabular}{cccccccc}
\hline Variables & N & Mean & SD & t-cal & t-tab & df & P \\
\hline Academic Staff & 100 & 15.435 & 5.81 & 0.167 & 1.96 & 198 & 0.05 \\
Non-Teaching Staff & 100 & 15.267 & 5.72 & & & & \\
\hline
\end{tabular}

In Table 3 above, analysis showed no significant difference between academic staff $(\mathrm{N}=100, \mathrm{X}=15.435, \mathrm{SD}=5.81)$ and non-teaching staff $(\mathrm{N}=100, \mathrm{X}=15.267, \mathrm{SD}$ $=5.72$ ) perception of industrial disputes in public universities in Southwest, Nigeria. The T-test analysis also revealed that the $t$-cal value 0.167 is not greater than the t.tab value of 1.96 at 00.5 level of significance.

Since the calculated value (0.167) is not greater than the table value (1.96), the null hypothesis which states that there is no significant difference in the way academic staff and non-teaching staff perceive industrial disputes is hereby upheld. This signifies that there is no significant difference in the way academic staff and non-teaching staff perceive industrial disputes in public universities in Southwest, Nigeria.

The results as shown in Tables 1 and 2 indicated that there is significant difference in the way university management and academic staff, university management and non-teaching staff perceive industrial disputes. The plausible reason for such difference in their perception may lie in the fact that the University management represents the employer and most of the time, employers of labour tend to perceive industrial disputes as a distraction and a share waste of precious time in the production process. Both the academic staff and non-teaching staff are workers and their interest in the institutions may not always be congruent with that of the management. University management tend to believe that whatever the grievances the workers may have, it is always better to come to the table and have a discussion. Good as the position might be, the problem that always lead to industrial dispute is the inability of the management to implement agreement freely entered into with the workers. The management may sometimes want to use their own parameters to measure what is adequate for the workers without considering the necessary inputs that should normally come from the workers' unions. 
Johnson Fejoh, Michael Ayodeji Boyede, Abiola Olawale Sanusi.

Industrial Actors` Perceptions of Industrial Disputes in Public Universities

This has always been a major source of industrial dispute in public tertiary institutions. While the management will be interested in uninterrupted academic calendar, little attention may be paid to the demands of the workforce, especially in the areas of collective agreement freely and jointly entered into. Inadequate fund has always been the culprit as far as management is concerned and they are quick to think that the workers should understand their plight and therefore cooperate with them. These findings are in consonance with the study carried out by Longe (2015) who affirmed that the causal factors of conflict in the world of work are multi-dimensional and they are based on economic and incompatibility of goals at workplace. In addition, the findings also corroborate Hotepo et al (2010) who affirmed that several factors such as, lack of resources, divergent expectation, workplace competition and communication breakdown have been identified as the root cause of major industrial disputes in organizations.

Meanwhile, findings from Table 3 indicated that there is no significant difference in the way academic staff and non-teaching staff perceive industrial disputes. The basis for this rests on the fact that both academic staff and non-teaching staff are workers and in most, if not all the cases see themselves as being in the same boat. Their perceptions of industrial disputes may not likely vary since both have their unions that are committed to the welfare of their members as they see industrial disputes as the ultimate vehicle to drive home their points if the management fails to accede to their requests of willingly neglect implementation of collective agreement jointly reached and signed with them. This finding corroborates the work of Ajewole (2014) who asserted that the major causes of industrial disputes in public universities in Nigeria among others include the inability of Federal Government of Nigeria to honour its agreement with university based unions. In this scenario, workers will perceive industrial dispute as the only way to fight for their labour rights.

\section{Conclusion}

Industrial disputes remain a major problem in the management of public universities in Nigeria. Public universities have experienced more industrial disputes in recent times and these have led to closure of these institutions with all the attendant consequences such as low productivity among the workforce and the production of ill-equipped graduates. This study examined how university managements, academic staff and non-teaching staff perceive industrial disputes and it was found out that while university managements see industrial disputes as unnecessary and a waste of production time, the academic staff and non-teaching staff see industrial disputes as the last resort in the fight for their welfare. 


\section{Recommendations}

The following recommendations were made based on the above findings and conclusion.

- Industrial disputes are not necessarily destructive if properly managed by the parties concerned. It is a manifestation of discontentment and grievances from either of the parties involved. It should be seen in the positive light for the university management to make necessary adjustment for efficient service delivery.

- All industrial actors in public universities in Southwest Nigeria should not see industrial disputes as destructive engagement since disputes are naturally part of human existence. Effective management and timely handling of industrial disputes through sincerity of purpose should be the key to sustainable industrial peace in public universities in Southwest, Nigeria.

- Management of public universities should endeavor to implement collective agreement freely and jointly entered into with the staff unions as this will reduce industrial disputes in these institutions to the barest minimum.

\section{References}

1. ABDUL, G. A \& SEHAR, S. (2015) Conflict management and organizational performance: A case study of Askari Bank Ltd. Research Journal of Finance and Accounting, 6 (11), p. 88-102.

2. ABU, P. B. (2007). Evolution of industrial relations in Nigeria. In K. Alebiosu \& D. Akintayo, eds., Readings in Industrial Relations. Ago-Iwoye: Institute of Education, Olabisi Onabanjo University.

3. ADOMI, E. \& ANIE, S. (2005). Conflict management in Nigerian university libraries. Journal of Library Management, 27(8), p. 520-530.

4. AGBA, A. M., USHIE, E. M., \& AGBA, M. S. (2009). External factors in industrial crises in Nigeria Civil Service. Nigerian Journal of Labour and Industrial Relations, 3(3), p. 75-94.

5. AGBA, A. M. \& USHIE, E. M. (2013). Wage differentials and industrial disputes in Nigerian hospitals. IOSR Journal of Business and Management, 11(5), p. $1-12$.

6. AJEWOLE, I. P. (2014).Managing labour unrest in Nigerian universities. Journal of Education and Policy Review, 6(2), p. 93-107

7. AKINBODE, J. O. \& EBELOKU, A. L. (2017). Understanding industrial relations system in Nigeria. ( $2^{\text {nd }}$ Edition). Ibadan: Kenny D Printers.

8. AKINBODE, J. O. (2019). Industrial disputes in Nigeria. A lecture delivered at 
Johnson Fejoh, Michael Ayodeji Boyede, Abiola Olawale Sanusi.

Industrial Actors` Perceptions of Industrial Disputes in Public Universities

the award of fellowship and induction of new members of Chartered Institute of Labor and Industrial Relations. http://doi.org/10.13140/RG.2.2.35634.04803.

9. AMINU, D. \& MARFO, C. (2010). Managing workplace conflict in the school environment: Challenges, rewards and the way forwards. Journal of Language, Technology and Entrepreneurship in Africa, 2 (2), p. 31-48. http://doi.org/104314/ jolte.v212.61520.

10. ANKU-TSEDE, O. \& ADJADOGO, N. (2016). Empirical analysis of workplace conflict and its influence on the attitude of media employees in Ghana. Journal of Management Policy and Practice, 17(1), p. 106-117.

11. AYOKO, O. B., ASHKANASY, N. M., \& JEHN, K. (2014). Handbook of conflict management research. http://doi.org/10.4337/9781781006948.

12. BADEKALE, A. F., NGIGE, C. V., \& HAMMA, J. I. (2016). Assessment of the impact of industrial disputes on teaching effectiveness of academics staff in Adamawa State Polytechnic, Yola, Nigeria. International Journal of Capacity Building in Education and Management, 3(1), p. 59-66

13. CHEN, I., CHEN, Y., \& CHEN, S. (2018). The strategic choice of payment method in corporate acquisition: The role of collective bargaining against unionized workers. Journal of Banking and Finance, 88, p. 408-422. http://doi.org/10.1016/J.J bank fin. 2018.01-009.

14. DARIA, P. \& BAHAUDIN, M. (2015). Conflict management practices for diverse workplaces. Journal of Business Studies Quarterly, 6(2), p. 13-22.

15. DE DREU, C.K., HARINCK, F., \& VAN VIANEN, A. E. (1999). Conflict and performance in groups and organizations. International Review of Industrial and Organizational Psychology, 14, p. 376-405.

16. DHRENDORF, R. (1976). Class and class conflicts in industrial society. London: Routledge and Kegan Paul.

17. EZEAGBA, E. C. (2014). Effects of strike cost on economics development in Nigeria. International Journal of Arts and Humanities, 3(3), p. 26-34.

18. FEJOH, J. \& ADESANWO, E. A. (2021). Impact of Tertiary Education Trust Fund (TETFUND) interventions on industrial peace in Olabisi Onabanjo University, Ago-Iwoye, Ogun State. Izvestiya Journal of Varna University of Economics, 65(1), p. 120-135. http://doi.org/10.36997/IJUEV2021.65.1.120

19. GALPIN, T. J. (1996). The human side of change: A practical guide to organization redesign. New York: Jossey-Bass.

20. HOTEPO, O. M., ASOKERE, A. S., ABDUL-AZEEZ, I. A., \& AJEMUIGBOLOHUN, S. A. (2010). Empirical study of the effects of conflict on organizational performance in Nigeria. Business and Economic Journal, 15(1), p. 1-9.

21. IGBAJI, P. (2009). Industrial conflict and goal achievement of tertiary 
institutions in Cross River State, Nigeria. Journal of Research in National Development, $7(2)$, p. $122-135$

22. KAN, W. \& MANFRED, E. (2017). Workers' unrest and institutional change: Perceptions of local trade union leaders in China. China Information, 3(1), p. 84-106.

23. KERSLEY, B. O., ALPIN, C., FORTH, J., BRYSON, A., BEWLEY, H., DIX, G., \& OXENBRIDGE, S. (2006). Inside the workplace: Findings from the 2004 workplace employment relations survey. London: Routledge.

24. KOLAWOLE, I. O. (2019). Effects of industrial conflicts on employees' performance in a private sector organization (A case of Ikeja Electricity Distribution Company Plc). European Journal of Business and Management, 11(24), p. 117-125. http://doi.org/10.7176/EJBM/11-24-13.

25. LANGTON, N. \& ROBBINS, S. P. (2006). Organizational behavior: Concepts, controversies, applications. Toronto: Pearson Prentice-Hall.

26. LIPSKEY, D. B., RONALD, L. S., \& ARIEL, C. A. (2015). From the negotiating arena to conflict management. Negotiation Journal, 31 (4), p. 405-413.

27. LONGE, O. (2015). Impact of workplace conflict management on organizational performance: A case of Nigerian Manufacturing Firm. Journal of Management and Strategy, 6(2), p. 83-92. http://doi.org/10. 5430/jms.v6n2p83.

28. NELSON, D. \& QUICK, J. (2001). Organizational behavior: Foundations, realities and challenges. Cincinnati, $\mathrm{OH}$ : South-Western.

29. OBASAN, K. A. (2011). Impact of conflict management on corporate productivity: An evaluative study. Australian Journal of Business Management Research, 5, p. 44-49.

30. OFFEM, O. O., ANASHIE, A. I., \& ANIAH, S. A. (2018). Effects of strikes on management and planning of educational activities in Nigerian universities. Global Journal of Educational Research, 17, p. 1-8.

31. OHIWEREI, F. O. \& OMO-OJUGO, M. O. (2008). Causes of conflict in banking industry. International Business Management Medwell Journal, 2(4), p. 132144.

32. OMISORE, B. O. \& ABIODUN, A. R. (2014). Organizational conflicts: Causes, effects and remedies. International Journal of Academic Research in Economics and Management Sciences, 3(6), p. 118-137. http://doi.org/10.6007/IJAREMS/V3i6/1351.

33. OMOTERE, T. (2014). Effects of ASUU strikes on the academic performance of university students. Ijebu-Ode: Ego Booster Books.

34. OTOBO, D. (2005). Industrial relations: Theory and controversies. Lagos: Malthouse Press Ltd.

35. RAHIM, M. A. (2010). Managing conflicts in organization. Piscataway NJ: 
Johnson Fejoh, Michael Ayodeji Boyede, Abiola Olawale Sanusi.

Industrial Actors` Perceptions of Industrial Disputes in Public Universities

Transaction Publishers.

36. ROBBINS, S. P., ODENDAAL, A., \& ROODT, G. (2003). Organizational behaviour: Global and South African perspectives. Cape Town: Pearson Education.

37. STROH, L. K. (2002). Organizational behaviour: A management challenge. Fort Worth, TX: Dryden.

38. TJOSVOLD, D. (2008). The conflict-positive organization; It depends upon us. Organizational Behaviour, 29, p. 19-28.

39. VAN TONDER, C. L. \& ROODT, G. (2008). Contemporary challenges and emerging issues in organization development: Theory and practice. Pretoria: Van Schaik.

40. WAHAB, B. (2018). All the Time ASUU has Gone on Strike Since 1999. [online] Available at www.pulse.ng/communities/student/all-the-time-asuu-has-goneon-strike-since-1999 [Accessed 15 Aug. 2020]

41. WEIDER-HATFIELD, D. \& HATFIELD, J. D. (1995). Relationships among conflict management styles, levels of conflict, and reactions to work. Journal of Social Psychology, 135 (6), p. 687-698. https://doi.org/10.1080/00224545.1995.9713972 